\title{
Augmented Reality in the Secondary Education classroom: Teachers' Visions
}

\author{
Verónica Marín-Díaz \\ University of Cordoba, Spain \\ ORCID: 0000-0001-9836-2584 \\ Begoña Sampedro \\ University of Cordoba, Spain \\ ORCID: 0000-0002-5617-0135 \\ Jorge Figueroa \\ Department Teacher Education, Texas Woman's University, Denton (Texas), USA \\ ORCID: 0000-0002-0276-5352
}

Received: 9 Aug 2021

Accepted: 18 Oct 2011

\begin{abstract}
The advancement of emerging technologies in the classroom is a reality, however, the vision that teachers may have of them is essential in order for these to be incorporated. Using this as a foundation, this article's main objective is to know the vision that secondary education (SE) teachers have of the use of Augmented Reality (AR) in teaching at that educational level. Through a descriptive correlational quantitative study, an ex-post facto design, and an ad-hoc questionnaire of 39 items, ( $N=350$ teachers), this objective has been corroborated. The main conclusion that has been reached is that SE teachers consider AR as an element that will cause a change in the student's learning methodology making it more autonomous and experiential. In addition, the teachers will need more training with AR, lower costs, and greater availability of resources to carry out the teaching process with greater ease.
\end{abstract}

Keywords: secondary education, professor, augmented reality, emergent technologies

\section{INTRODUCTION}

Information and Communication Technologies (ICTs), as pointed out by Puerta-Cortés and Carbonell (2013), contribute to improving people's lives in general. In particular, in the educational field, their presence has meant the reconstruction of the teaching and learning systems that both teachers and students had created over the decades of "analog" training.

In this sense, the integration of digital tools into classrooms implies, on the one hand, taking into account the beliefs, visions and training that teachers have towards them, and on the other hand, the student's position when linking the use of technology to their own learning. Likewise, education administrators will also play a starring role since they will be initially facilitating not only their academic integration, but also economically, in educational centers.

Focusing the attention on the teacher, there are various studies that have been carried out over the years on their positions about integrating technologies and classroom methodologies (Acosta et al., 2019; CaicedoTamayo \& Rojas-Espina, 2014; Cassany \& Llach, 2017). We found research in which the use of e-learning 
platforms, especially Moodle, for the development of teaching was detected, also resistance of some teachers to the integration of mobile devices in classrooms (Cassany \& Llach, 2017), the possibilities of being able to link the collaborative work of the students (Acosta et al., 2019), being able to make learning a reality (Martos \& Teruel, 2018), etc. In this sense, the opinion, beliefs and visions that pre-service teachers have about ICTs at a general level is an important element to be considered and integrated to the educational dynamics in a standardized way.

Following this trend is that the work that follows is presented. It showcases the opinion of Secondary Education (SE) teachers on the link between ICTs in general and particularly Augmented Reality in the SE curriculum. The main result of the study was that $S E$ teachers have a positive vision of the integration of AR for learning at this educational level. Hence, it has been possible to conclude, initially, that teachers need training in accordance with the pedagogical use of this resource for its incorporation into the classroom.

\section{AR IN EDUCATION}

For more than a decade the so-called emerging technologies have been making an impact in educational institutions. In some cases, they've become the element on which the entire teaching-learning process pivots.

According to Burke and Fedorek (2017), the 21st century student requires educational initiatives that implement the use of higher-order thinking (analysis, synthesis and evaluation). In that regard, the integration of AR becomes a resource that promotes it since the link between the students with the content is total. As Yilmaz (2016) points out, it provides simultaneity in learning by providing a real situation a linkage to a real context (Wu et al., 2013). Is that link between the real and virtual context the one that implies that it becomes a tool that facilitates the formative process of the students. The literature indicates that the main advantages of using AR in education revolve around its great possibilities of immersion in the content to be covered (Rodríguez-García et al., 2019; Yip et al., 2019). Also it use with mobile devices such as tablets and smartphones (Gutiérrez et al., 2018), improves the learning performance (Chang et al., 2015; Wang, 2017) and information processing along with an increase in the student comprehension and memory (Chiang et al., 2014). In addition, it enhances student motivation (Hsio, 2013; Sommerauer \& Müller, 2014), encourages innovation (Lovos, 2019), abstract learning develops (Wang, 2017) as well as affective, attractive, and experiential (de la Horra, 2016; Estepa \& Nadolny, 2015) and promotes student research (Gómez et al., 2020).

On the other hand, it should be noted that AR in education, in particular, also implies a series of disadvantages or negative aspects that must be taken into account when introducing it into the classroom. These revolve around the complexity of the technology itself, the cost or the compatibility of the devices (Gómez et al., 2020; Hsio, 2013; Marín-Díaz, 2017; Villalustre, 2020), the price of the applications and devices (Yip et al., 2019), design errors that slow down the learning devices (Akçayır \& Akçayır, 2017; Gavilanes et al., 2018), the difficulty of using it for students with visual needs (Chiang et al., 2014; Marín-Díaz, 2017) and the lack of teacher training to create materials (Marín-Díaz, 2017; Toledo \& García, 2017).

In any case, and in general, AR in education creates an active learning environment (Marín-Díaz, 2017), under a constructivist approach towards the learning process, thus teaching innovations and research experiences at different educational levels have highlighted how the curriculum can be worked using a transversal approach to develop the student's abilities (Rodríguez-García et al., 2019). Along that same line we find various contributions which draw the same perspective of success. For example, in a study conducted by De la Torre et al. (2013), with students enrolled in secondary school and in college, it was found that AR was a tool that had a direct relation between the concept of volume and tridimensional models. In addition, Hung et al. (2016) demonstrated that after using the ARtool Kit with their Chinese students, the learning of the Chinese language improved. On the other hand, the study carried out by Weng et al. (2019) found that the content of a Biology course was improved by using books which integrated AR. In the same way Fernandez (2017), conducted a study with pre-service teachers in which it was found that providing feedback with AR promoted an understanding of the content. 
Villalustre (2020) conducted a study which involved its undergraduate students in the design of training for the areas of mathematics, science and language with the use AR. The main finding had to do with the didactic potential to the learning experience by integrating $A R$ and its development by the students. Finally, the work of Sanusi et al. (2018) carried out through mobile devices and focusing in the learning of content for the class History of Architecture, confirmed the findings of other research that used AR in the classroom and concluded that its use with mobile devices benefited the flexible and intuitive learning of the students. Lastly, Villota and Vasconez (2020) conducted first-hand experimentation when they develop an AR app for first aid training named First Aid with Augmented Reality (FARWAR). It was implemented in Ecuador with doctors, paramedics, and other volunteers. Its first results have reflected that being able to use these resources allowed simulations to be carried out at any time, thus promoting autonomous learning of first aid techniques.

As we can see, the use of this emerging technology implies being able to access different training environments that were not previously present in the classrooms. This implies a process of teaching methodologies renewal, as well as the beliefs and visions of both students and teachers.

\section{METHODOLOGY}

For this descriptive correlational quantitative study an ex-post facto design (León \& Montero, 2011) was used along with an ad-hoc questionnaire that followed current country legislation (Real Decreto 1105/2014). The study sought to determine the vision of SE teachers with the integration of AR in that educational level. It had the following specific objectives:

1. Describe the vision of SE teachers around the possibility of using AR with students that are labeled with Specific Educational Support Needs (SESN).

2. Clarify the existence of differences in the different work models (collaborative, group, and cooperative).

3. Analyze the vision of SE teachers about classroom work mediated by AR while studying the comprehensive and detailed influence of independent variables such as gender and age.

The working hypotheses emanating from these objectives were:

$\mathrm{H} 1$ : There are significant differences depending on the macro-area of work origin.

H2: Women are more favorable to the use of AR in SE for curriculum development.

H3: Younger teachers have a more positive view of incorporating AR as a methodological element in secondary classrooms.

\section{Instrument}

For the development of the investigation, an ad hoc questionnaire was created based on the legislation that regulates the studies of SE in Spain (Royal Decree 1105/2014). The instrument was composed of a total of 39 items. The first 4 corresponded to the socio-demographic variables of the participants (age, gender, area of knowledge and device). The remaining 35 were distributed around 6 dimensions.

In order to verify the reliability of the instrument and validity of the construct, a Cronbach's Alpha test was carried out along with an Exploratory Factor Analysis (EFA). The alpha value of the entire questionnaire was .815 , ranging from $\alpha=.804$ (item 4) to $\alpha=.825$ (item 9), in the item-scale test if some item was excluded, meaning that all of them were higher $\alpha=.804$, indicating that each item analyzed measures a segment of a characteristic to be studied. Also, when trying to measure the discrimination capacity of the items (Hernández et al., 2014), a student's t test was performed as a function of the $25 \%$ minimum and maximum value of the highest and lowest cases of the scores of the item of a new variable, calculated from the sum of the values of the variables considered, whose results showed a high discriminatory power in all of them. Thus, we can point out that the reliability achieved is high (Mateo, 2012). Regarding the validity of the construct, the EFA performed with an extraction method of principal components with a Kaiser normalized Varimax rotation with values higher than one and loads higher than .30, yielded a total of 6 factors or 
Table 1. EFA

\begin{tabular}{|c|c|c|c|c|c|c|}
\hline \multirow{2}{*}{ Items } & \multicolumn{6}{|c|}{ Factors (Dimensions) } \\
\hline & 1 & 2 & 3 & 4 & 5 & 6 \\
\hline
\end{tabular}

The use of Augmented Reality (AR) will make the teaching methodology used in the .619 classroom more active.

The use of Augmented Reality (AR) will make the teaching methodology used in the .597 classroom achieve, more effectively, the objectives of the subject in which it is used.

The use of Augmented Reality (AR) will favor the personal initiative of students.

The use of Augmented Reality (AR) will make the teaching methodology used in the .549 classroom promote the development of key competences.

The use of Augmented Reality (AR) will help in solving problems related to the subject in .516 which it is used.

The use of Augmented Reality (AR) will make the teaching methodology used in the .494 classroom more participatory.

The use of Augmented Reality (AR) will make the teaching methodology used in the .484 classroom more communicative.

The use of Augmented Reality (AR) will help in carrying out complex tasks associated with .461 real situations or as contextualized as possible, linked to the subject in which it is used.

The use of Augmented Reality (AR) will promote the critical spirit of students.

The use of Augmented Reality (AR) can be used by students with high abilities.

The use of Augmented Reality (AR) will favor the creativity of students.

The use of Augmented Reality (AR) will favor the interaction of students. 406

\begin{tabular}{ll}
\hline The use of Augmented Reality (AR) can enhance intercultural education. & .761
\end{tabular}

The use of Augmented Reality (AR) can enhance multicultural education. $\quad .720$

$\begin{array}{ll}\text { The use of Augmented Reality (AR) promotes education in values. } & .626\end{array}$

Augmented Reality (AR) can help prevent bullying.

Augmented Reality (AR) allows transversal learning of content.

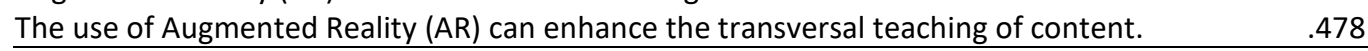

Learning to use Augmented Reality (AR) by students takes a long time.

To use Augmented Reality (AR) in the classroom, you need great technological support. $\quad .705$

To use Augmented Reality (AR) in the classroom it is necessary to have computer and / or $\quad .680$

programming knowledge.

Learning to use Augmented Reality (AR) by teachers takes a long time.

Augmented Reality (AR) is easy for students to use.

The use of Augmented Reality (AR) allows collaborative work.

The use of Augmented Reality (AR) allows group work.

$-.666$

The use of Augmented Reality (AR) allows cooperative work.

Augmented Reality (AR) can be used by students with motor skill difficulties.

Augmented Reality (AR) can be used by students with psychological difficulties.

Augmented Reality (AR) can be used by students with visual difficulties.

Augmented Reality (AR) can be used by students who have specific educational needs

Augmented Reality (AR) can be used by students with hearing difficulties

.879

.879
.874

.873

The use of Augmented Reality (AR) fosters the development of the capacity to dialogue

and express in public the content of the subject to which it is linked.

The use of Augmented Reality (AR) encourages oral expression linked to the subject in which it is used.

The use of Augmented Reality (AR) will favor students' ability to communicate what they have learned.

The use of Augmented Reality (AR) fosters reading comprehension of texts related to the subject in which it is used.

dimensions (Table 1), which explained $67.313 \%$, of the total variance explained $(\mathrm{KMO}=.763$; Chi2 $=$ 5476.188; $g l=630 ; p=.000)$.

Once the Alpha-Cronbach test was carried out on each of the factors, it was confirmed that the reliability of the instrument remained high (Mateo, 2012) with the exception of factor 3 which dealt with the technological knowledge of the tool and its development and had a low alpha value (see Table 2). 
Table 2. Reliability of dimensions

\begin{tabular}{ll}
\hline Dimensions & Alpha \\
\hline Dimension 1. AR mediated classroom work & .785 \\
Dimension 2. AR and socio-educational vision & .769 \\
Dimension 3. AR and technological competence & .534 \\
Dimension 4. AR and learning development & .926 \\
Dimension 5. AR and SESN & .708 \\
Dimension 6. AR and linguistic competence & .714 \\
\hline
\end{tabular}

Table 3. Distribution of the sample by age

\begin{tabular}{llc}
\hline & F. & $\%$ \\
\hline $24-30$ years & 90 & 25.7 \\
$31-40$ years & 85 & 24.3 \\
$41-50$ years & 86 & 24.6 \\
$>50$ years & 89 & 25.4 \\
\hline
\end{tabular}

Table 4. Distribution of the sample according to the device used

\begin{tabular}{lcc}
\hline & F. & $\%$ \\
\hline Smartphone & 134 & 38.3 \\
Desktop & 57 & 16.3 \\
Laptop & 52 & 14.9 \\
Tablet & 11 & 3.1 \\
Tablet+Smartphone & 4 & 1.1 \\
Laptop+Smartphone +Tablet & 8 & 2.3 \\
Desktop+ Smartphone & 34 & 9.7 \\
Laptop +Smartphone & 37 & 10.5 \\
Desktop + Smartphone +Tablet & 13 & 3.7 \\
\hline
\end{tabular}

\section{Sample}

The population participating in this study is a group of SE teachers, with $\mathrm{N}=350$ of which $57.1 \%$ were women. The mean age of the participants is 39.51 (DT. = 11.109). See the distribution on Table 3.

Considering the macro-work area, the one with the most presence is Art and Humanities (40.6\%), followed by Engineering and Architecture (22.3\%), Social and Legal Sciences (18.9\%) and Experimental Sciences $(15.7 \%)$, and the one with the least presence is that of Health Sciences $(2.6 \%)$.

Regarding the mobile devices that have to work or connect with AR we saw that $38.3 \%$ of the participants use smartphone compared to 2.3 that use a Tablet (see Table 4).

\section{Procedure}

After the instrument was designed, the administration of the instrument was carried out by means of a mass mail to SE teachers in which a Google Drive link was provided. The data collection period was the academic year 2018-2019.

\section{Analysis of Data}

The analysis of the data was quantitative, with a basic description of the variables, through the measurements of central tendency (mean) and dispersion (standard deviation), as well as the distribution measurements (asymmetry and kurtosis). Also, variance analysis tests were performed to observe the possible existence of differences as a function of the independent variables (gender, age, and macro area) through the use of Student's t-test and an ANOVA. Likewise, to verify the relationship between dimensions of the questionnaire, an analysis was performed with bivariate correlations. Lastly, a multiple linear regression multivariate analysis was performed, to seek an adequate explanatory model of the relationships 
Table 5. Descriptive study

\begin{tabular}{|c|c|c|c|c|}
\hline Item & $\mathrm{M}$ & S.D. & Asymmetry & Kurtosis \\
\hline 1 & 4.43 & .629 & -.863 & .717 \\
\hline 2 & 3.77 & .737 & -.214 & -.181 \\
\hline 3 & 4.11 & .675 & -.635 & 1.028 \\
\hline 4 & 4.01 & .766 & -.514 & .047 \\
\hline 5 & 3.92 & .711 & -.696 & 1.743 \\
\hline 6 & 4.13 & .773 & -.760 & .837 \\
\hline 7 & 3.95 & .822 & -.770 & .396 \\
\hline 8 & 4.21 & .702 & -1.015 & 2.497 \\
\hline 9 & 3.57 & .870 & -.269 & .011 \\
\hline 10 & 4.62 & .547 & -1.385 & 2.751 \\
\hline 11 & 4.28 & .714 & -1.079 & 2.304 \\
\hline 12 & 4.20 & .690 & -1.233 & 3.931 \\
\hline 13 & 4.24 & .673 & -.554 & .201 \\
\hline 14 & 4.30 & .671 & -.546 & -.234 \\
\hline 15 & 3.61 & .898 & -.317 & -.320 \\
\hline 16 & 3.25 & .858 & -.276 & .091 \\
\hline 17 & 4.26 & .618 & -.820 & 3.208 \\
\hline 18 & 4.44 & .577 & -.528 & -.138 \\
\hline 19 & 2.46 & .983 & .751 & -.147 \\
\hline 20 & 3.28 & 1.184 & -.052 & -1.259 \\
\hline 21 & 3.19 & 1.213 & -.443 & -1.164 \\
\hline 22 & 3.11 & 1.089 & .144 & -1.159 \\
\hline 23 & 3.84 & .808 & -.876 & .755 \\
\hline 24 & 4.32 & .742 & -1.227 & 2.329 \\
\hline 25 & 4.25 & .775 & -1.095 & 1.668 \\
\hline 26 & 4.28 & .736 & -1.065 & 1.891 \\
\hline 27 & 3.92 & .827 & .954 & 1.046 \\
\hline 28 & 3.99 & .776 & -.758 & .842 \\
\hline 29 & 3.06 & 1.263 & -.022 & -1.186 \\
\hline 30 & 4.37 & .789 & -1.452 & 2.494 \\
\hline 31 & 4.36 & .593 & -.655 & 1.834 \\
\hline 32 & 3.35 & .918 & -.336 & -.321 \\
\hline 33 & 3.23 & .902 & -.278 & -.535 \\
\hline 34 & 3.89 & .820 & -.795 & .751 \\
\hline 35 & 3.75 & .912 & -.552 & -.228 \\
\hline
\end{tabular}

between the dimensions of the study, and corresponding to other predictive elements that determined the sample. All of these analysis were performed with the SPSS v.23 software program.

\section{RESULTS}

\section{Descriptive}

In general, the descriptive study of the data shown in Table $\mathbf{5}$ demonstrates that the participating teachers favor the use of AR in SE. It is significant, as in item 16 (AR can help prevent bullying), and shown as a behavior of indifference $(44.6 \%)$ and agreement $(33.7 \%)$, which can be interpreted as a certain inclination to the possibility that they are prone to use it.

It is worth noting a majority position of disagreement that students and teachers need a long time to learn to use AR (item 19, 54.9\% and 36.3\%).

On the other hand, it is notable that the sample disagrees (32\%) and agrees (32.3\%) with the statement that they need great technological support in classrooms to use AR (item 20). 
Table 6. t-test on gender

\begin{tabular}{|c|c|c|c|c|c|}
\hline & & $\mathrm{N}$ & M. & DT. & $\mathrm{T}, \mathrm{p}$ y d of Cohen \\
\hline \multirow[t]{2}{*}{ Dimension 1} & Male & 150 & 48.1267 & 5.37743 & $\mathrm{~T}=-3.826 ; p .=.000 ; \mathrm{d}=-.43$ \\
\hline & Female & 200 & 50.1650 & 4.26836 & \\
\hline \multirow[t]{2}{*}{ Dimension 2} & Male & 150 & 23.3267 & 3.15271 & $\mathrm{~T}=-4.185 ; p .=.000 ; \mathrm{d}=-.46$ \\
\hline & Female & 200 & 24.6650 & 2.68305 & \\
\hline \multirow[t]{2}{*}{ Dimension 5} & Male & 150 & 20.0933 & 2.92030 & $\mathrm{~T}=2.172 ; \mathrm{p} .=; .031 \mathrm{~d}=.23$, differences have been assumed in \\
\hline & Female & 200 & 19.4000 & 3.00084 & favor of women \\
\hline \multirow[t]{2}{*}{ Dimension 6} & Male & 150 & 13.2133 & 2.66367 & $\mathrm{~T}=-4,454 ; p .=.031 ; \mathrm{d}=-.49$ \\
\hline & Female & 200 & 14.4500 & 2.44076 & \\
\hline
\end{tabular}

\section{Inferential}

A t-Test for independent samples was performed and took into account the 6 dimensions and gender as a contrast variable, there were no significant differences found in dimensions 3 and 4 . Regarding dimensions $1,2,5$ and 6 , it should be noted that the differences found were reflected in favor of women. Demonstrating a greater predisposition to the use of AR in the curricular development of the secondary classroom, as well as within the sphere of inclusive education and denoting a greater burden in terms of technical and time knowledge that technology needs.

In order to establish the existence or not existence of differences according to age, we categorized this variable in 4 intervals: $24-30$ years; $31-40$ years; $41-50$ years and over 50 years. Based on the factors (dimensions) achieved, it has been verified that in dimension $1\left[\mathrm{~F}(3,346)=3,570, \mathrm{p} .=.014 ; \eta^{2}=.030\right]$ there are significant differences between teachers aged $31-40$ years $[t(346)=3.02, p .=.016]$ who consider that the use of $A R$ is positive for the development of curricular work in the classroom versus to those of 41-50 years. In the other dimensions, there are no differences regarding the age variable.

If we focus the attention on the curricular areas, we found that in the first dimension $[F(4,345)=5,614, p .=$. $\left.000 ; \eta^{2}=.06\right]$, the teachers that belong to the Engineering-Architecture macro-area consider the use of AR in the classroom favorable in comparison to the faculty from Art-Humanities [ $t=(345)=3.18 ; p=.016]$. Following this we also found that teachers belonging to Social and Legal Sciences considered AR as a valuable tool in the classroom as opposed to those of Art-Humanities [t (345) $=3.57 ; p=.004$ ].

In the second dimension $\left[F(4,345)=4,798 ; p=.001 ; \eta^{2}=.05\right]$, we saw that the teachers of the Engineering and Architecture macro-areas [t $(345)=3.45 ;$ p. $=.006$ ], Social and Legal Sciences [t $(345)=3.35 ; \mathrm{p} .=.009$ ] and Health Sciences [t $(345)=3.02 ;$ p. $=.027$ ] were more favorable to having a socio-educational vision of RA than the teachers of Experimental Sciences.

In dimension $5\left[\mathrm{~F}(4,345)=2,982 ; \mathrm{p} .=.019 ; \eta^{2}=.03\right]$ we verified that the teachers of Social and Legal Sciences $[t(345)=3.09 ; p .=.021]$ were more inclined to present a positive vision of the relationship between AR and SESN than those of Art and Humanities.

Lastly, the sixth dimension, referring to the link between AR and language skills $[F(4,345)=3,911 ;$ p. $=.004$, $\left.\eta^{2}=.04\right]$, are the members of Engineering and Architecture [t $\left.(345)=3.13 ; \mathrm{p} .=.019\right]$, who were more favorable than those of Experimental Sciences.

\section{Correlational}

The correlational study carried out between the 6 dimensions indicated the existence of relationships between the different factors at a bilateral significance level of .01. As it can be sees in Table 7, these relationships were not shown in all cases, since factor 3 only correlated with 5.

For all these reasons, we can establish a link between the items that make up the third dimension related to the learning time of the technology, as well as the need for computer or programming knowledge with those of the fifth, which refer to the possibility of using the AR by students with different needs (psychological, motor, visual and auditory). 
Table 7. Correlational study of the dimensions

\begin{tabular}{|c|c|c|c|c|c|c|c|}
\hline & & Factor 1 & Factor 2 & Factor 3 & Factor 4 & Factor 5 & Factor 6 \\
\hline \multirow[t]{2}{*}{ Factor 1} & $\mathrm{R}$ & 1 & & & & & \\
\hline & $P$ & & & & & & \\
\hline \multirow[t]{2}{*}{ Factor 2} & $\mathrm{R}$ & $.533(* *)$ & 1 & & & & \\
\hline & $P$ & .000 & & & & & \\
\hline \multirow[t]{2}{*}{ Factor 3} & $\mathrm{R}$ & -.013 & .034 & 1 & & & \\
\hline & $P$ & .811 & .522 & & & & \\
\hline \multirow[t]{2}{*}{ Factor 4} & $\mathrm{R}$ & $.397(* *)$ & $.307(* *)$ & -.019 & 1 & & \\
\hline & $\mathrm{P}$ & .000 & .000 & .721 & & & \\
\hline \multirow[t]{2}{*}{ Factor 5} & $\mathrm{R}$ & $.232\left(^{* *}\right)$ & $.265\left(^{* *}\right)$ & $-.184(* *)$ & .092 & 1 & \\
\hline & $P$ & .000 & .000 & .001 & .086 & & \\
\hline \multirow[t]{2}{*}{ Factor 6} & $\mathrm{R}$ & $.442(* *)$ & $.362(* *)$ & .015 & $.257(* *)$ & $.160(* *)$ & 1 \\
\hline & $\mathrm{P}$ & .000 & .000 & .786 & .000 & .003 & \\
\hline
\end{tabular}

Table 8. Multiple linear regression of classroom work mediated by $\mathrm{AR}^{\mathrm{a}}$

\begin{tabular}{|c|c|c|c|c|}
\hline & \multicolumn{4}{|c|}{ Variables } \\
\hline & Constant $^{\mathrm{b}}$ & $A R$ and vision ${ }^{b}$ & AR and competence ${ }^{b}$ & AR and development ${ }^{\mathrm{b}}$ \\
\hline$B$ & 22.041 & .604 & .481 & .459 \\
\hline E.S & 1.847 & .074 & .083 & .101 \\
\hline Beta & & .375 & .262 & .202 \\
\hline $\mathrm{t}$ & 11.937 & 8.115 & 5.771 & 4.536 \\
\hline Sig. & $.000^{*}$ & $.000^{*}$ & $.000^{*}$ & $.000^{*}$ \\
\hline Zero Order & & .532 & .450 & .384 \\
\hline Partial R & & .400 & .296 & .237 \\
\hline Semi-partial R & & .339 & .241 & .190 \\
\hline Tolerance & & .820 & .846 & .881 \\
\hline VF & & 1.219 & 1.183 & 1.135 \\
\hline
\end{tabular}

Note: a. Dependent variable: Classroom work mediated by AR (Dimension 1); b. Predictors: (Constant), AR and socio-educational vision (Dimension 2), AR and linguistic competence (Dimension 6), and AR and learning development (Dimension 4).

*. Level of significance $p=0.05$

\section{Multiple Linear Regression}

In the search for an analysis that indicates how the different dimensions were related, we carried out a multiple linear regression using the successive steps method, where the equation that most favorably explains the work in the classroom mediated by $A R, F(3,347)=75.293$ and $p<.005$, with a corrected determination level $R 2=0.39$ and an interdependence of the residuals measured by the Durbin-Watson value $=2.12$ (Gil, 2015), is subject to the intervention of the variables $A R$ and socio-educational vision $(t=8,115$ and $p<.005)$; to $A R$ and linguistic competence $(t=5,771$ and $p<.005)$; and $A R$ and learning development $(t=$ $4,536$ and $p<.005)$.

According to Table 8, the equation of classroom work mediated by $A R=22.041+0.6 \mathrm{AR}$ and socioeducational vision $+0.48 \mathrm{AR}$ and Linguistic competence $+0.46 \mathrm{AR}$ and learning development. Likewise, the study of the residuals revealed the generality of the model by means of non-multicollinearity (seen in the table through the IVF values), the homoscedasticity and the linearity of the residuals that are studied in the graphs meet these assumptions (Hancock et al., 2019); and, finally, the normality test was applied to these $(\mathrm{Z}=0.053$ and $\mathrm{p}=0.200)$.

Likewise, to check how the equation behavior of the explanatory model of classroom work mediated by AR according to gender, we used the same as the selection variable, being the coefficients that are derived for males and expressed in Table 9.

Considering the distribution of the sample according to male gender, $F(3,146)=28,034$ and $p<.005$, with an R2 $=0.366$ and a Durbin-Watson value of 2.1 (noting the interdependence of the residuals, Gil, 2015), it has the following variables: AR and socio-educational Vision ( $t=4,149$ and $p<.005)$; AR and learning development $(t=4,053$ and $p<.005)$; and $A R$ and linguistic competence $(t=2.007$ and $p=0.047)$. By this means that the 
Table 9. Multiple lineal regression of classroom work mediated by AR for males ${ }^{a}$

\begin{tabular}{|c|c|c|c|c|}
\hline & \multicolumn{4}{|c|}{ Variables } \\
\hline & Constant $^{b}$ & AR and vision ${ }^{b}$ & AR and competence ${ }^{b}$ & AR and development ${ }^{\mathrm{b}}$ \\
\hline$B$ & 22.410 & .563 & .644 & .314 \\
\hline E.S & 2.849 & .136 & .159 & .157 \\
\hline Beta & & .330 & .290 & .155 \\
\hline $\mathrm{t}$ & 7.865 & 4.149 & 4.053 & 2.007 \\
\hline Sig. & $000^{*}$ & $000^{*}$ & $000^{*}$ & $.047^{*}$ \\
\hline Zero Order & & .515 & .456 & .409 \\
\hline Partial R & & .325 & .318 & .164 \\
\hline Semi-partial $R$ & & .274 & .267 & .132 \\
\hline Tolerance & & 689 & .850 & .726 \\
\hline VF & & 1.452 & 1.177 & 1.378 \\
\hline
\end{tabular}

Note: a. Dependent variable: Classroom work mediated by AR (Dimension 1); b. Predictors: (Constant), AR and socio-educational vision (Dimension 2), AR and learning development (Dimension 4), and AR and linguistic competence (Dimension 6).

*. Level of significance $p=0.05$

Table 10. Multiple lineal regression of classroom work mediated by AR for females ${ }^{\mathrm{a}}$

\begin{tabular}{|c|c|c|c|c|}
\hline & \multicolumn{4}{|c|}{ Variables } \\
\hline & Constant $^{b}$ & $A R$ and vision ${ }^{b}$ & AR and competence ${ }^{b}$ & AR and development ${ }^{\mathrm{b}}$ \\
\hline B & 23.024 & .628 & .569 & .264 \\
\hline E.S & 2.499 & .086 & .094 & .128 \\
\hline Beta & & .418 & .345 & .120 \\
\hline $\mathrm{t}$ & 9.213 & 7.262 & 6.024 & 2.058 \\
\hline Sig. & $.000^{*}$ & $.000^{*}$ & $.000^{*}$ & $.041^{*}$ \\
\hline Zero Order & & .499 & .434 & .293 \\
\hline Partial R & & .460 & .395 & .145 \\
\hline Semi-partial R & & .404 & .335 & .115 \\
\hline Tolerance & & .933 & .944 & .911 \\
\hline VF & & 1.072 & 1.060 & 1.098 \\
\hline
\end{tabular}

Note: a. Dependent variable: Classroom work mediated by AR (Dimension 1); b. Predictors: (Constant), AR and socio-educational vision (Dimension 2), AR and linguistic competence (Dimension 6), and AR and learning development (Dimension 4).

*. Level of significance $p=0.05$

resulting equation of classroom work mediated by $A R$ for males $=22,410+0.56$ AR and socio-educational vision +0.64 AR and learning development +0.31 AR and language proficiency.

In reference to the residuals of this regression, the non-multicollinearity is supported by the IVF value obtained; the homoscedasticity and the linearity of the same observed in the graphs, fulfill these assumptions (Hancock et al., 2019); in addition, the normality values of the residuals using the Kolmogorov-Smirnov test $(\mathrm{Z}=0.043$ and $\mathrm{p}=0.193)$.

While, for females, the multiple linear regression using the successive steps method, the equation that best explains classroom work mediated by $\operatorname{AR}$ is $F(3,196)=42,365$ and $p<.005$, with a corrected level of determination R2 $=0.39$ and an interdependence of the residuals measured by the Durbin-Watson value $=$ 1.99 (Gil, 2015). This is subject to the intervention of the variables $A R$ and socio-educational vision $(t=7,262$ and $p<.005)$; $A R$ and linguistic competence $(t=6.024$ and $p<.005)$; and $A R$ and learning development $(t=$ $2,058$ and $p=0.041)$. This is showcased in Table 10.

From what is extracted from Table 10, the equation of classroom work mediated by AR for females $=23,024$ $+0.6 R A$ and socio-educational vision + 0.57 AR and linguistic competence + 0.26AR and learning development. Likewise, the study of the residuals revealed the generality of the model by means of nonmulticollinearity (seen in the table through the IVF values), the homoscedasticity and the linearity of the residuals that are studied in the graphs meet these assumptions (Hancock et al., 2019); and, finally, the normality test was applied to these $(Z=0.046$ and $p=0.200)$.

The following multiple linear regression using the successive steps method has age as a selection variable, specifically the sample of 24 to 30 years, where the summary of the model is as follows: $F(3.88)=14,510$ 
Table 11. Multiple linear regression of classroom work mediated by AR with subjects between the ages of 24-30 years $^{\mathrm{a}}$

\begin{tabular}{lcccc}
\hline & \multicolumn{3}{c}{ Variables } \\
\hline B & Constant $^{\mathrm{b}}$ & AR and vision $^{\mathrm{b}}$ & AR and competence $^{\mathrm{b}}$ & ${\text { AR } \text { and development }^{\mathrm{b}}}^{\mathrm{N}}$ \\
E.S & 23.024 & .628 & .569 & .264 \\
Beta & 2.499 & .628 & .094 & .128 \\
T & & .418 & .345 & .120 \\
Sig. & 9.213 & 7.262 & 6.024 & .058 \\
Zero Order & $.000^{*}$ & $.000^{*}$ & $.000^{*}$ & $.041^{*}$ \\
Partial R & & .499 & .434 & .293 \\
Semi-partial R & .460 & .395 & .145 \\
Tolerance & & .404 & .335 & .115 \\
VF & & .933 & .944 & .911 \\
\hline
\end{tabular}

Note: a. Dependent variable: Classroom work mediated by AR (Dimension 1); b. Predictors: (Constant), AR and socio-educational vision (Dimension 2), AR and learning development (Dimension 4), and AR and linguistic competence (Dimension 6).

*. Level of significance $p=0.05$

Table 12. Multiple lineal regression of classroom work mediated by AR with subjects between the ages of $31-40$ years $^{\mathrm{a}}$

\begin{tabular}{lccc}
\hline & & Variables \\
\hline B & Constant $^{\mathrm{b}}$ & AR and vision & \\
E.S & 29.723 & .576 & AR and competence $^{\mathrm{b}}$ \\
Beta & 3.533 & .152 & .493 \\
$\mathrm{t}$ & & .375 & .171 \\
Sig. & 8.414 & 3.788 & .285 \\
Zero Order & $.000^{*}$ & $.000^{*}$ & 2.877 \\
Partial R & & .489 & $.005^{*}$ \\
Semi-partial R & .382 & .435 \\
Tolerance & & .344 & .300 \\
VF & & .841 & .261 \\
\hline NFta. & 1.190 & .841 \\
\end{tabular}

Note: a. Dependent variable: Classroom work mediated by AR (Dimension 1); b. Predictors: (Constant), AR and socio-educational vision (Dimension 2), and AR and linguistic competence (Dimension 6).

*. Level of significance $p=0.05$

and $p<.005$, with an R2 $=0.33$ and a Durbin-Watson value of 2.2 (noting the interdependence of the residuals, Gil, 2015), has the following variables, reflected in Table 11: AR and socio-educational vision ( $t=$ $3,331$ and $p=0.001) ; A R$ and learning development $(t=2,229$ and $p=0.028)$; and $A R$ and linguistic competence $(t=2,114$ and $p=0.037)$. By this means the resulting equation of classroom work mediated by $A R$ for males $=21.609+0.53 \mathrm{AR}$ and socio-educational vision $+0.61 \mathrm{AR}$ and learning development $+0.48 \mathrm{RA}$ and linguistic competence.

In reference to the residuals of this regression, the non-multicollinearity is supported by the IVF value obtained; the homoscedasticity and the linearity of the same observed in the graphs, fulfill these assumptions (Hancock et al., 2019); in addition, the normality values of the residuals using the Kolmogorov-Smirnov test $(Z=0.047$ and $p=0.200)$.

When considering, the age from 31 to 40 years, the equation that best explained classroom work mediated by $A R$ is $F(2.84)=18.635$ and $p<.005$, with a corrected level of determination of $R 2=0.31$ and an interdependence of the residuals measured by the Durbin-Watson value $=2.0$ (Gil, 2015). This is subject to the intervention of the variables AR and socio-educational vision $(t=3,788$ and $p<.005)$; $A R$ and linguistic competence $(t=2,877$ and $p=0.005)$. The equation of classroom work mediated by $A R$ for people between 31 and 40 years old $=29,723+0.57$ AR and socio-educational vision +0.49 AR and linguistic competence. This is seen in Table 12. 
Table 13. Multiple lineal regression of classroom work mediated by AR with subjects between the ages of $41-50$ years $^{\mathrm{a}}$

\begin{tabular}{lccc}
\hline & & \multicolumn{2}{c}{ Variables } \\
\hline B & Constant $^{\mathrm{b}}$ & AR and vision & \\
E.S & 31.793 & .623 & AR and competence \\
Beta & 3.591 & .133 & .332 \\
$\mathrm{t}$ & & .460 & .159 \\
Sig. & 8.853 & 4.667 & .205 \\
Zero Order & $.000^{*}$ & $.000^{*}$ & 2.081 \\
Partial R & & .532 & $.041^{*}$ \\
Semi-partial R & .463 & .368 \\
Tolerance & & .430 & .227 \\
VF & & .875 & .192 \\
\hline
\end{tabular}

Note: a. Dependent variable: Classroom work mediated by AR (Dimension 1); b. Predictors: (Constant), AR and socio-educational vision (Dimension 2), and AR and linguistic competence (Dimension 6).

*. Level of significance $p=0.05$

Table 14. Multiple linear regression for classroom work mediated by AR for subjects over 50 years ${ }^{a}$

\begin{tabular}{|c|c|c|c|c|}
\hline & \multicolumn{4}{|c|}{ Variables } \\
\hline & Constant $^{\mathrm{b}}$ & AR and vision ${ }^{b}$ & AR and competence ${ }^{b}$ & AR and development ${ }^{b}$ \\
\hline$B$ & 18.080 & .847 & .452 & .314 \\
\hline E.S & 2.662 & .129 & .162 & .134 \\
\hline Beta & & .547 & .223 & .177 \\
\hline $\mathrm{T}$ & 6.792 & 6.572 & 2.793 & 2.335 \\
\hline Sig. & .000 & .000 & .006 & .022 \\
\hline Zero Order & & .740 & .567 & .495 \\
\hline Partial R & & .583 & .292 & .247 \\
\hline Semi-partial R & & .443 & .188 & .157 \\
\hline Tolerance & & .656 & .715 & .787 \\
\hline VF & & 1.523 & 1.399 & 1.271 \\
\hline
\end{tabular}

Note: a. Dependent variable: Classroom work mediated by AR (Dimension 1); b. Predictors: (Constant), AR and socio-educational vision (Dimension 2), AR and learning development (Dimension 4), and AR and linguistic competence (Dimension 6).

*. Level of significance $p=0.05$

On the other hand, the study of the residuals revealed the generality of the model by means of nonmulticollinearity (seen in the table through the IVF values), the homoscedasticity and the linearity of the residuals that are studied in the graphs meet these assumptions (Hancock et al., 2019); and, finally, the normality test was applied to these $(Z=0.043$ and $p=0.193)$.

Likewise, the equation that best explains classroom work mediated by AR for subjects between the ages of 41 to 50 years is $F(2.80)=18,840$ and $p<.005$, with a corrected determination level of $R 2=0.32$ and an interdependence of the residuals measured by the Durbin-Watson value $=2.2$ (Gil, 2015). They are subject to the intervention of the variables to $A R$ and linguistic competence $(t=4.667$ and $p<.005)$; and $A R$ and socioeducational vision $(t=2,081$ and $p=0.041)$. From what is extracted from Table 13, the equation of classroom work mediated by AR for subjects between the ages of 41 to 50 years $=31,793+0.62$ AR and linguistic competence + 0.33AR and socio-educational vision.

The study of the residuals revealed the generality of the model by means of non-multicollinearity (seen in the table through the IVF values), the homoscedasticity and the linearity of the residuals that are studied in the graphs meet these assumptions (Hancock et al., 2019); and, finally, the normality test was applied to these $(Z=0.039$ and $p=0.200)$.

Finally, to check how the equation of the explanatory model behaved regarding classroom work mediated by $A R$, for subjects over 50 years, we used the same variable selection. The coefficients derived for this age group are presented in Table 14. 
Considering the distribution of the sample of the subject with an age over 50 years the equation was $F$ (3.84) $=45,393$ and $p<.005$, with an R2 $=0.62$ and a Durbin-Watson value of 2.2 (indicating the interdependence of the residues, Gil, 2015). It had the following variables reflected in Table 14: AR and socio-educational vision $(t=6,572$ and $p<.005) ; A R$ and learning development $(t=2,793$ and $p=0.006)$; and $A R$ and linguistic competence $(t=2,335$ and $p=0.022)$. The resulting equation of classroom work mediate by AR for subjects over 50 years $=18,080+0.84 \mathrm{AR}$ and socio-educational vision $+0.45 \mathrm{AR}$ and learning development $+0.31 \mathrm{AR}$ and language proficiency.

In reference to the residuals of this regression, the non-multicollinearity is supported by the IVF value obtained; the homoscedasticity and the linearity of the same is observed in the graphs, it fulfilled these assumptions (Hancock et al., 2019); in addition, to the normality values of the residuals using the Kolmogorov-Smirnov test $(Z=0.039$ and $p=0.200)$.

In summary, the model that explained classroom work mediated by AR considered AR and socio-educational vision, AR and learning development and AR and linguistic competence as variables; however, as it can be seen when including gender and age as selection variables, the equation of this explanatory model is altered by age, both from 31 to 40 years and from 41 to 50 years, where only the dimensions are AR and the socioeducational vision and $A R$ and linguistic competence.

\section{DISCUSSION AND CONCLUSIONS}

Like Cook et al. (2018), we think that AR will take us to a point where its primary role will be to improve our lives in general and the learning environments in particular. Advancing in teaching and learning involves the incorporation of new strategies, procedures and methodologies that will involve the introduction of digital resources to help both the teacher and the student in their educational process.

In general, the predispositions of SE teachers are positioned in to a positive vision of the use of AR for learning at this educational level (Fuentes et al., 2019; Garay et al., 2017; Lai et al., 2019; Rivadilla \& Rodríguez, 2020; Weng et al., 2019).

Regarding the link of curriculum development and AR with SESN (objective 1), in general, all the 5 macroareas remained positively, as does the research of Chang (2014), Marín-Díaz (2017), del Cerro and Morales (2018), and Martínez (2020). It is significant to mention that SE teachers in the area of Social and Legal Sciences were inclined to consider their integration as positive (Chang 2014; Cozar et al, 2015; Marín-Díaz, 2017; Martínez, 2020).

In regards to the hypothesis, $\mathrm{H} 1$ (There are significant differences depending on the macro-area of work origin) was studied in terms of dimension 1 which included its use in the classroom, its socio-educational vision, its use in inclusive areas and relationships, and as an element that enhances linguistic competence. $\mathrm{H} 1$ must be accepted as it was verified with the answers provided by the SE teachers from the areas of Engineering and Architecture (De la Torre et al., 2013; Sanusi et al., 2018) and those of Social and Legal Sciences (Márquez-Díaz \& Morales-Espino, 2020). For dimension 2, it must also be accepted, since the representativeness in the areas of Engineering and Architecture, Social and Legal Sciences and Health Sciences, considered that it will enhance a critical vision of both the educational and social sphere in students compared to the areas that do not considered it. It is striking that only SE teachers linked to the Social Sciences manifested this in dimension 5, referring to inclusive education (Marín-Díaz, 2017, 2018). Finally, the sixth dimension can only be accepted say in the area of Health Sciences.

With regard to $\mathrm{H} 2$ (Women are more favorable to the use of AR in SE for curriculum development), it should be noted that this only occurred in relation to the link between AR and inclusive education (SESN) showcased in dimension 5. Therefore, we can conclude that there are no differences around the overlapping of AR and the secondary education curriculum and gender (del Cerro \& Morales, 2017). Likewise, it can be seen, as if there are differences regarding the model that explained classroom work mediated by $A R$, in which it revealed that females get closer to it than males. 
The third hypothesis (Younger teachers have a more positive view of incorporating AR as a methodological element in secondary classrooms) indicated that SE teachers between the ages from 31 to 40 years exhibited a more positive view. With this finding the hypothesis should be rejected with some caution due to the fact that the youngest participants were between the ages of 24-30. With respect to the model that explained classroom work mediated by AR, it was observed that the youngest (24-30 years) and the oldest (over 50 years) approached this model in comparison to those who did not considered the dimension of $A R$ and learning development as part of it.

As main conclusions to this study we can indicate that: the areas of Art and Humanities are not openly inclined to the incorporation of AR in the secondary education curriculum and development, unlike the investigations that reflected its usefulness. For the contents that are worked and studied in this field (Fidan \& Tuernel, 2019), the youngest educators are not excessively open to their integration and that it is the social profiles that are most open to their use in the field of inclusion.

Finally, it can be concluded that, in general, SE considered AR as an element that will cause a change in the student's learning methodology, making it more autonomous and experiential and, as far as they are concerned, they will need more training with this tool, reduction of costs and greater availability of resources to be able to carry out the teaching process with greater ease.

It should also be mentioned that future studies on classroom work mediated by AR or didactic methodology based on this technology, should address the behaviors that macro-areas present and the use with different devices.

\section{LIMITATIONS}

The development of an investigation in the field of social sciences involves a main handicap regarding the sample size. The initial virtues of this study were to put on the table the voice of the SE teachers who are not the object of constant studies in this field. Likewise, research that is structured through SE teachers indicates that high amount of instructors enter various macro-areas, which means that some have more students than others, usually in Art and Humanities than those of Health Sciences. In addition, the variety in the age of the same by the complexity of the studies from which they come and other types of life cycle are important factors. This last fact implies the variety and plurality in the use of devices, which makes the study of these aspects extremely complicated.

Author contributions: All authors were involved in concept, design, collection of data, interpretation, writing, and critically revising the article. All authors approve final version of the article.

Funding: The authors received financial support for the research and authorship of this article from project: DIVEMIX: Design, implementation and evaluation of mixed reality materials for learning environments (PID2019-108933GB-I00) funded by the Spanish Ministry of Science and Innovation.

Declaration of interest: Authors declare no competing interest.

Data availability: Data generated or analysed during this study are available from the authors on request.

\section{REFERENCES}

Acosta, R., Martín, A. V., \& Hernández, A. (2019). Uso de las metodologías de aprendizaje colaborativo con TIC: Un análisis desde las creencias del profesorado [Use of collaborative learning methodologies with ICT: An analysis from teachers' beliefs]. Digital Education Review, 35, 309-323. https://doi.org/10.1344/der.2019.35.309-323

Akçayır, M., \& Akçayır, G. (2017). Advantages and challenges associated with augmented reality for education: A systematic review of the literature. Educational Research Review, 20, 1-11. https://doi.org/10.1016/j.edurev.2016.11.002

Burke, A., \& Fedoreck, B. (2017). Does flipping promote engagement?: a comparison of a traditional online and flipped class. Active Learning in Higher Education, 18(1), 11-24. http://doi.org/10.1177/1469787417693487 
Caicedo-Tamayo, A. M., \& Rojas-Ospina, T. (2014). Creencias, conocimientos y usos de las TIC de los profesores universitarios [Beliefs, knowledge and uses of ICT by university professors]. Educación y Educadores, 17(3), 517-533. https://doi.org/10.5294/edu.2014.17.3.7

Cassany, D., \& Llach, S. (2017). La digitalización del aula de ciencias: creencias y prácticas [The digitization of the science classroom: beliefs and practices]. Digital Education Review, 31, 93-115. https://doi.org/10.1344/der.2017.31.93-115

Chang, Y. L., Hou, H. T., Pan, C. Y., Sung, Y. T., \& Chang, K. E. (2015) Apply an augmented reality in a mobile guidance to increase sense of place for heritage places. Educational Technology \& Society, 18(2), 166178. https://www.jstor.org/stable/pdf/jeductechsoci.18.2.166.pdf

Chiang, T. H. C., Yang, S. J. H., \& Hwang, G. (2014). An augmented reality-based mobile learning system to improve students' learning achievements and motivations in natural science inquiry activities. Journal of Educational Technology \& Society, 17(4), 352-365. www.jstor.org/stable/jeductechsoci.17.4.352

de la Horra, I. (2016). Realidad aumentada, una revolución educativa [Augmented reality, an educational revolution]. EDMETIC, Revista de Educación Mediática y TIC, 6(1), 9-22. https://doi.org/10.21071/edmetic.v6i1.5762

De la Torre, J., Martin-Dorta, N., Saorín Pérez, J. L., Carbonell, C., \& Contero, M. (2013). Entorno de aprendizaje ubicuo con realidad aumentada y tabletas para estimular la comprensión del espacio tridimensional [Ubiquitous learning environment with augmented reality and tablets to stimulate understanding of three-dimensional space]. Revista De Educación a Distancia (RED), 37. https://revistas.um.es/red/article/view/234041

del Cerro, F., \& Morales, G. (2017). Augmented reality as a tool for improving spatial intelligence in secondary education students. RED. Revista de Educación a Distancia, 54, 5. https://doi.org/10.6018/red/54/5

del Cerro, F., \& Morales, G. (2018). Augmented reality and mobile devices: A binominal methodological resource for inclusive education (SDG 4). An example in secondary education. Sustainability, 10, 3446. https://doi.org/10.3390/su10103446

Estepa, A., \& Nadolny, L. (2015). The effect of an augmented reality enhanced mathematics lesson on student achievement and motivation. Journal of STEM Education, 16(3), 40-48. https://pdfs.semanticscholar.org/ed4b/76e1662dd2486354b06fec29f6a8dc5fc827.pdf

Fernández, B. (2016). Factores que influyen en el uso y aceptación de objetos de aprendizaje de realidad aumentada en estudios universitarios de Educación Primaria [Factors that influence the use and acceptance of augmented reality learning objects in primary education university studies]. EDMETIC, Revista de Educación Mediática y TIC, 6(1), 203-220. https://doi.org/10.21071/edmetic.v6i1.5815

Fidan, M., \& Tuncel, M. (2019). Integrating augmented reality into problem based learning: The effects on learning achievement and attitude in physics education. Computers \& Education, 142, 103635. https://doi.org/10.1016/j.compedu.2019.103635

Fuentes, A., López, J., \& Pozo, S, (2019). Análisis de la competencia digital docente: Factor clave en el desempeño de pedagogías activas con realidad aumentada [Analysis of teaching digital competence: Key factor in the performance of active pedagogies with augmented reality]. REICE, Revista Iberoamericana sobre Calidad, Eficacia y Cambio en Educación, 17(2), 27-42. https://doi.org/10.15366/reice2019.17.2.002

Garay, U., Tejada, E., \& Castaño, C. (2017). Percepciones del alumnado hacia el aprendizaje mediante objetos educativos enriquecidos con realidad aumentada [Students' perceptions of learning through educational objects enriched with augmented reality]. EDMETIC, Revista de Educación Mediática y TIC, 6(1), 145-164. https://doi.org/10.21071/edmetic.v6i1.5812 
Gavilanes, W., Abásolo, M. J., \& Cuji, B. (2018). Resumen de revisiones sobre realidad aumentada en educación [Summary of reviews on augmented reality in education]. Revista Espacios, 39(15), 1-14. http://sedici.unlp.edu.ar/bitstream/handle/10915/73208/Documento_completo.pdf-

PDFA. pdf? sequence=1\&isAllowed $=y$

Gil, J. A. (2015). Metodología cuantitativa en educación. UNED.

Gómez, G., Rodríguez, C., \& Marín, J. A. (2020). La trascendencia de la realidad aumentada en la motivación estudiantil. Una revisión sistemática y meta-análisis [The importance of augmented reality in student motivation. A systematic review and meta-analysis]. Alteridad, 15(1), 36-46. https://doi.org/10.17163/alt.v15n1.2020.03

Gutiérrez, R. S., Duque, E. T., Chaparro, R. L., \& Rojas, N. R. (2018). Aprendizaje de os conceptos básicos de realidad aumentada por medio del juego Pokemon Go y sus posibilidades como herramienta de mediación educativa en Latinoamérica [Learning the basic concepts of augmented reality through the game Pokemon Go and its possibilities as an educational mediation tool in Latin America]. Información Tecnológica, 29(1), 49-58. https://doi.org/10.4067/S0718-07642018000100049

Hancock, G. R., Stapleton, L. M., \& Mueller, R. O. (2019). The reviewer's guide to quantitative methods in the social sciences. (2nd ed.). Routledge.

Hernández, R., Fernández, C., \& Baptista, P. (2014). Metodología de la investigación [Investigation methodology]. McGraw Hill Education.

Hsio, K. (2013). Using augmented reality to students health-care of combining educational learning with standard fitness. Multimedia Tools and Application, 64, 407-421. https://doi.org/10.1007/s11042-0110985-9

Hung, Y.-H., Chen, C. H., \& Huang, S. W. (2016). Applying augmented reality to enhance learning: A study of different teaching materials. Journal of Computer Assisted Learning, 27, 1-13. https://doi.org/10.1111/jcal.12173

Lai, A., Chen, C., \& Lee, G. (2019). An augmented reality-based learning approach to enhancing students' science reading performances from the perspective of the cognitive load theory. British Journal of Educational Technology, 50(1), 232-247. https://doi.org/10.1111/bjetc.12716

León, O., \& Montero, I. (2011). Métodos de investigación en psicología y educación [Research methods in psychology and education]. McGraw Hill.

Lovos, E. N. (2019). Material educativo aumentado. Análisis de una experiencia de usuario [Increased educational material. Analysis of a user experience]. EDUTEC, 70. https://doi.org/10.21556/edutec.2019.70.1331

Márquez-Díaz, J. E., \& Morales-Espinosa, L. A. (2020). Realidad aumentada como herramienta de apoyo al aprendizaje de las funciones algebraicas y trascendentes [Augmented reality as a support tool for learning algebraic and transcendent functions]. Revista Educación en Ingeniería, 15(29), 3441. https://doi.org/10.26507/rei.v15n29.1037

Martínez, S. (2020). Tecnologías de información y comunicación, realidad aumentada y atención a la diversidad en la formación del profesorado [Information and communication technologies, augmented reality and attention to diversity in teacher training]. Revista Transdigital, 1(1), 1-20. https://www.revista-transdigital.org/index.php/transdigital/article/view/9

Martos, F., \& Teruel, M. (2018). Plataformas virtuales en ELE: análisis y evolución del Aula Virtual de Español (AVE), según creencias de su profesorado [Virtual platforms in EL: analysis and evolution of the Virtual Spanish Classroom (AVE), according to the beliefs of its teachers]. marcoELE. Revista de Didáctica Español Lengua Extranjera, 26, https://www.redalyc.org/jatsRepo/921/92155180012/92155180012.pdf

1885-2211. 
Puerta-Cortés, D. X., \& Carbonell, X. (2013). Uso problemático de Internet en una muestra de estudiantes universitarios colombianos [Problematic Internet use in a sample of Colombian university students].

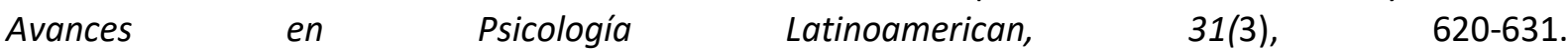
https://revistas.urosario.edu.co/index.php/apl/article/view/2231

Royal Decree 1105/2014, of December 26, which establishes the basic curriculum for Compulsory Secondary Education and Baccalaureate, published in BOE no. January 3, 2015. https://www.boe.es/buscar/act.php?id=BOE-A-2015-37

Rodríguez-García, A., Hinojo-Lucena, F. J., \& Agreda-Montoro, M. (2019). Diseño e implementación de una experiencia para trabajar la interculturalidad en Educación infantil a través de realidad aumentada y códigos QR [Design and implementation of an experience to work interculturality in Early Childhood Education through augmented reality and QR codes]. Educar, 55(1), 59-77. https://doi.org/10.5565/rev/educar.966

Sanusi, A. N. Z., Abdullah, F., Kassim, M. H., \& Tidjani, A. A. (2018). Architectural history education: Students' perception on mobile augmented reality learning experience. Advanced Science Letters, 24(11), 81718175. https://doi.org/10.1166/asl.2018.12517

Sommerauer, P., \& Müller, O. (2014). Augmented reality in informal learning environments: A field experiment in a mathematics exhibition. Computers \& Education, 79, 59-68. https://doi.org/10.1016/j.compedu.2014.07.013

Toledo, P., \& Sánchez, J. M. (2017). Realidad aumentada en educación primaria: Efectos sobre el aprendizaje [Augmented reality in primary education: Effects on learning]. RELATEC, Revista Latinoamericana de Tecnología Educativa, 16(1), 79-97. https://doi.org/10.17398/1695-288X.16.1.79

Villalustre, L. (2020). Propuesta metodológica para la integración didáctica de la realidad aumentada en educación infantil [Methodological proposal for the didactic integration of augmented reality in early childhood education]. EDMETIC, Revista de Educación Mediática y TIC, 9(1), 170-187. https://doi.org/10.21071/edmetic.v9i1.11569

Villota, W. R., \& Vásconez, J. (2020). La capacitación en primeros auxilios con el empleo de la realidad aumentada [Training in first aid with the use of augmented reality]. Revista Espacios, 41(13), 1-13. http://www.revistaespacios.com/a20v41n13/20411312.html

Wang, Y. (2017). Exploring the effectiveness of integrating augmented reality-based materials to support

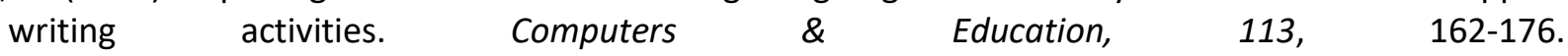
https://doi.org/10.1016/j.compedu.2017.04.013

Weng, C., Otanga S., Christianto, S. M., \& Chu, R. J. (2019). Enhancing students' biology learning by using augmented reality as a learning supplement. Journal of Educational Computing Research, 58(4), 747770. https://doi.org/10.1177/0735633119884213

Wu, H., Lee, W., Chang, H., \& Liang, C. (2013). Current status, opportunities and challenges of augmented reality in education. Computes \& Education, 62, 41-49. https://doi.org/10.1016/j.compedu.2012.10.024

Yilmaz, R. M. (2016). Educational magic toys developed with augmented reality technology for early childhood education. Computers in Human Behaviour, 54, 240-248. https://doi.org/10.1016/j.chb.2015.07.040

Yip, J., Wong, S., Yick, K., Chan, K., \& Wong, K. (2019). Improving quality of teaching and learning in classes by using augmented reality video. Computers \& Education, 128, 88-101. https://doi.org/10.1016/j.compedu.2018.09.014 